\title{
Cardiac Toxicity Associated with Immune Checkpoint Inhibitors: Case Series and Review of the Literature
}

\author{
Nikhil Agrawal ${ }^{a} \quad$ Arjun Khunger $^{\mathrm{b}} \quad$ Pankit Vachhani $^{\mathrm{c}} \quad$ Teresa A. Colvin $^{\mathrm{a}}$ \\ Alexander Hattoum ${ }^{\mathrm{a}}$ Edward Spangenthal ${ }^{\mathrm{C}}$ Anne B. Curtis ${ }^{\mathrm{a}}$ \\ Grace K. Dy ${ }^{\mathrm{a}, \mathrm{c}}$ Marc S. Ernstoff ${ }^{\mathrm{a}, \mathrm{c}}$ Igor Puzanov \\ aDepartment of Medicine, Jacobs School of Medicine and Biomedical Sciences at the \\ University at Buffalo, Buffalo, NY, USA; bDepartment of Hematology and Oncology, \\ Taussig Cancer Institute, Cleveland Clinic, Cleveland, $\mathrm{OH}$, USA; 'Department of Medicine, \\ Roswell Park Comprehensive Cancer Center, Buffalo, NY, USA
}

\section{Keywords}

Cardiotoxicity $\cdot$ Immune checkpoint inhibitors $\cdot$ Myocarditis · Autoimmune $\cdot$ Cardio-oncology

\begin{abstract}
The development of immune checkpoint inhibitors (ICls) has revolutionized the treatment of patients with advanced stage cancers. However, immune-related adverse events are frequently observed. Cardiac toxicity from ICl therapy can range from asymptomatic troponin-I elevations to conduction abnormalities of the heart and even fulminant myocarditis. Although rare, myocarditis is a potentially fatal adverse effect of $\mathrm{ICl}$ therapy. We present a series of five cases of $\mathrm{ICl}$-related cardio-toxicity diagnosed and managed at Roswell Park Comprehensive Cancer Center along with a review of published case reports in the literature. Our series highlights the importance of high clinical suspicion, early diagnosis of myocarditis, and prompt initiation of immunosuppressive therapy.

(C) 2019 The Author(s)

Published by S. Karger AG, Basel
\end{abstract}




\section{Case Reports in Oncology}

Case Rep Oncol 2019;12:260-276

DOI: $10.1159 / 000498985$

(c)

(C) 2019 The Author(s). Published by S. Karger AG, Basel www.karger.com/cro

Agrawal et al.: Case Series of Cardiac irAEs

\section{Introduction}

Immune checkpoints refer to inhibitory pathways that are crucial for maintaining selftolerance and modulating physiological immune responses [1]. Tumor cells adapt the same pathways to avoid immune detection and destruction [1]. Two such pathways regulated by cytotoxic T-lymphocyte-associated antigen 4 (CTLA-4), and programmed cell death protein 1 (PD-1) and its ligand PD-L1 have been targeted successfully with the development of monoclonal antibodies blocking these immune checkpoints such as anti-CTLA4 agent (ipilimumab), anti-PD1 agents (nivolumab, pembrolizumab), and anti-PD-L1 agents (atezolizumab, durvalumab, avelumab) $[1,2]$. These monoclonal antibodies have received approval by the Food and Drug Administration (FDA) across several malignancies including melanoma, basal cell carcinoma, small-cell and non-small cell lung cancer (NSCLC), liver cancer, bladder cancer, renal cell carcinoma, Hodgkin's disease, and any solid tumor with a microsatellite instability-high (MSI-H) or mismatch repair deficient (dMMR) profile [3].

Despite these advances, system-wide adverse events associated with ICIs have been noted, termed as immune-related adverse events (irAEs). Gastrointestinal, dermatologic, hepatic and endocrine toxicities are among the most commonly observed irAEs [4]. Cardiovascular toxicities are among the rare organ toxicities of ICI therapy [5, 6]. With increased use of ICIs over the past few years, numerous reports of cardiovascular toxicities have emerged (summarized in Table 1, Table 2, Table 3) [7-35]. The most serious among them is the development of fulminant myocarditis, a potentially fatal clinical disease which has been the primary focus for the cardio-oncology community [12]. More common clinical presentations include acute onset heart failure, arrhythmias or atypical chest pain [36]. The incidence of myocarditis is relatively higher with combination blockade $(0.27 \%)$ of ipilimumab and nivolumab than with single agent anti-PD1/anti-PDL1 alone (0.06\%) [12]. Despite treatment with high doses of steroids, infliximab and anti-thymocyte globulin, the outcome has been fatal in a significant number of the reported cases [12]. Due to the rarity and often subtle initial presentations of cardiac irAEs, cases may be missed on initial presentation and hence it is imperative to characterize these severe yet uncommon toxic effects. Here we present a series of five cases of ICI-related cardiotoxicity diagnosed and managed at Roswell Park Comprehensive Cancer Center.

\section{Case Series}

\section{Case 1}

A 73-year-old man with Stage III malignant mesothelioma (mixed epithelioid, sarcomatoid, and desmoplatstic types) was noted to have disease progression after six cycles of carboplatin and pemetrexed and three cycles of maintenance pemetrexed. He then received one dose of off-label pembrolizumab $200 \mathrm{mg}$ intravenously (IV). Thirty-two days later, he presented with two days of progressive dyspnea, along with weight gain and fatigue. Electrocardiogram (ECG) and telemetry findings showed that the patient had alternating right (RBBB) and left bundle branch block (LBBB), episodes of asystole, and third-degree block with a junctional escape rhythm (Fig. 1a, b). Troponin I, CK, and CK-MB peaked at $8.3 \mathrm{ng} / \mathrm{mL}$ (normal, 0$0.10 \mathrm{ng} / \mathrm{mL}), 6124 \mathrm{u} / \mathrm{L}(45-185 \mathrm{IU} / \mathrm{L})$, and $99.1 \mathrm{ng} / \mathrm{mL}(0-5.0 \mathrm{ng} / \mathrm{mL})$ respectively. 


\section{Case Reports in Oncology}

Case Rep Oncol 2019;12:260-276

DOI: $10.1159 / 000498985$

(C) 2019 The Author(s). Published by S. Karger AG, Base www.karger.com/cro

Agrawal et al.: Case Series of Cardiac irAEs

Serological testing for influenza, coxsackie virus, and adenoviruses was found to be negative. An echocardiogram showed a left ventricular ejection fraction (LVEF) of 50-60\% with mild concentric left ventricular hypertrophy (LVH), mild right atrial enlargement, moderate left atrial enlargement, and mild aortic, mitral, and tricuspid regurgitation. The patient underwent nuclear stress testing to rule out an ischemic etiology, and it revealed normal myocardial perfusion and normal left ventricular wall motion with an LVEF of 64\%. Given the new onset intermittent $\mathrm{AV}$ block with elevated troponin and a negative stress test, a presumptive diagnosis of myocarditis was made. A permanent pacemaker was placed due to symptomatic bradycardia with improvement in symptoms. Additionally, heart failure symptoms were managed with lisinopril, metoprolol, and furosemide. The patient was discharged from the hospital post pacemaker implantation and a follow up echocardiogram was recommended. During the hospital course, the patient received two doses of oral prednisolone $60 \mathrm{mg}$ daily.

On follow-up the next week, the patient presented to the hospital with bilateral lower extremity weakness, ptosis and dysphagia. Given this clinical picture, a presumptive diagnosis of acute myasthenia crisis was made secondary to immunotherapy. He slowly developed progressive dyspnea ultimately requiring intubation. Treatment included pyridostigmine, 2 doses of $60 \mathrm{mg}$ oral prednisone, five doses of intravenous immunoglobulin (IVIG), and three sessions of plasmapheresis. Despite the treatment, there was little clinical improvement and after twenty days of symptom onset, patient was terminally extubated as per the family's wishes.

\section{Case 2}

A 64-year-old man with a history of hypertension, Castleman's disease, and prostate cancer was diagnosed with BRAF-mutated metastatic melanoma. Initially, he was started on Talimogene therapy, but he was switched to pembrolizumab after progression of disease was noted. He presented with a two-week history of increased fatigue, weakness, and myalgia, approximately four weeks after his first cycle of pembrolizumab. His symptoms included diplopia and decreased extraocular movements. On admission, he had a negative inspiratory force (NIF) less than $-40 \mathrm{~cm} \mathrm{H}_{2} \mathrm{O}$, concerning for acute myasthenia crisis.

Troponin-I was elevated to $0.78 \mathrm{ng} / \mathrm{mL}$ and his CK and CK-MB peaked at 1,681 IU/L and $159 \mathrm{ng} / \mathrm{mL}$ respectively. No ischemic changes were seen on initial ECG, but he was found to have a new RBBB and left anterior fascicular block on admission. Subsequent ECGs showed a prolonged PR interval with LBBB. Out of concern for both acute myasthenia crisis as well as myocarditis, he was immediately started on $1 \mathrm{~g}$ IV methylprednisolone for 3 days. A bedside echocardiogram was suggestive of a normal LVEF without wall motion abnormalities. Viral panel testing was negative for adenovirus, coxsackie virus, cytomegalovirus (CMV), and Epstein-Barr virus (EBV). Cardiac MRI, performed 2 days after immunosuppressive therapy was initiated, was negative by Lake Louise Criteria for any evidence of myocarditis. On hospital day 4, the LBBB was resolved and he was transitioned from IV methylprednisolone to oral prednisone $150 \mathrm{mg}$ daily. Troponin-I returned to baseline the next day. The diagnosis of myasthenia gravis was confirmed by the presence of anti-acetylcholinesterase antibodies, and the patient received 5 days of IV immunoglobulins along with pyridostigmine with improvement in his NIFs and diplopia. The patient was also given oral prednisone $50 \mathrm{mg}$ twice daily which was tapered over 1 week. 


\section{Case Reports in Oncology}

Case Rep Oncol 2019;12:260-276

DOI: $10.1159 / 000498985$

(c)

(C) 2019 The Author(s). Published by S. Karger AG, Base www.karger.com/cro

Agrawal et al.: Case Series of Cardiac irAEs

On the last follow-up visit, one year after the initial dose of pembrolizumab, the patient was noted to have stable disease on routine surveillance with no further toxicities reported.

Case 3

An 89-year old man with a history of diabetes mellitus type 2, hypertension, dyslipidemia, and post-operative atrial flutter was diagnosed with BRAF wild-type Stage IIa metastatic melanoma of the right arm for which he underwent wide local excision. Five years later, the disease recurred in his right axilla. Neoadjuvant pembrolizumab $2 \mathrm{mg} / \mathrm{kg}$ every three weeks was initiated. He developed weakness, myalgias, and dyspnea at rest approximately 12 days after the first dose of pembrolizumab. On presentation, labs were notable for CK 964 IU/L, CK-MB $104.4 \mathrm{ng} / \mathrm{mL}$, troponin-I $5.78 \mathrm{ng} / \mathrm{mL}$, brain natriuretic peptide (BNP) $105 \mathrm{pg} / \mathrm{mL}$ (0-99 $\mathrm{pg} / \mathrm{mL}$ ), aspartate aminotransferase $112 \mathrm{IU} / \mathrm{L}$ (AST; 15-46 IU/L), alanine aminotransferase 168 (ALT; 11-66 IU/L), and myoglobin 10,374 ng/mL (0-155 ng/mL). Complement levels were low; C3 $36 \mathrm{mg} / \mathrm{dL}$ (80-175 mg/dL) and C4 $6.5 \mathrm{mg} / \mathrm{dL}$ (14-40 mg/dL). Blood viral testing was negative for adenovirus, coxsackie virus, CMV, EBV, and human immunodeficiency virus (HIV). Serologies for hepatitis B, hepatitis C, and CMV were negative. A nasal swab detected the absence of respiratory syncytial virus (RSV), adenovirus, human metapneumovirus, influenza A and B, and parainfluenza 1, 2, and 3 strains. Screens for antinuclear antibody (ANA) and antineutrophil cytoplasmic antibody (p-ANCA and c-ANCA) were negative.

On presentation, his ECG demonstrated RBBB (Fig. 2) and a transthoracic echocardiogram showed right ventricular dilation with normal right systolic function and a hyperdynamic left ventricle with preserved regional wall motion. Given normal systolic function in the setting of acute biomarker rise and recent use of ICI, a diagnosis of myocarditis was reached. Treatment with methylprednisolone $1 \mathrm{~g}$ IV daily was started and was transitioned to oral prednisone $60 \mathrm{mg}$ twice daily. The patient developed complete heart block and an urgent trans-venous pacing wire was placed. Sinus rhythm with 2nd degree Mobitz I (Wenckebach) AV block with occasional dropped beats and pacing was achieved three days after original presentation. Due to the high incidence of case fatality from ICI-related myocarditis, and the established role of anti-thymocyte globulin (ATG) in cardiac transplant patients, additional immunosuppression with three doses of anti-thymocyte globulin (rabbit ATG) 125 mg daily was administered four days after the original presentation. Telemetry findings post-ATG course showed sinus rhythm. Unfortunately, the patient developed gram-positive bacteremia and septic shock, and he succumbed to ensuing multi-organ failure.

\section{Case 4}

A 65-year-old woman with a history of hypertension, mitral valve repair for severe mitral regurgitation, total laryngectomy for laryngeal cancer, and chemoradiation therapy (5-fluorouracil and Mitomycin) for stage IIIb anal canal squamous cell carcinoma was diagnosed with stage IV squamous cell carcinoma of the lung. The lung cancer progressed after four cycles of cisplatin, gemcitabine, and necitumumab. She was enrolled in a phase I clinical trial through which she received one dose each of the experimental drug and nivolumab $240 \mathrm{mg}$. Six days later, she presented with dyspnea on exertion. Labs showed CK-MB $2.2 \mathrm{ng} / \mathrm{mL}$, troponin-I 0.12 $\mathrm{ng} / \mathrm{mL}$, and BNP $330 \mathrm{pg} / \mathrm{mL}$. A mucus plug was aspirated and led to significant symptom relief. However, a day later, she again complained of exertional dyspnea. In addition, bilateral lower extremity edema and bradycardia (30-40 beats/min) was noted. Repeat BNP was 


\section{Case Reports in Oncology}

Case Rep Oncol 2019;12:260-276

DOI: $10.1159 / 000498985$

(c) 2019 The Author(s). Published by S. Karger AG, Basel www.karger.com/cro

Agrawal et al.: Case Series of Cardiac irAEs

elevated to $764 \mathrm{pg} / \mathrm{mL}$. An echocardiogram showed diffuse global hypokinesis. The ejection fraction was severely decreased to $25-30 \%$. Due to global left ventricular dysfunction in the setting of recent ICI therapy, the possibility of cardiotoxicity was raised over acute coronary syndrome, and she was started on methylprednisolone $1 \mathrm{~g}$ daily for 3 days. Additionally, she was treated with diuretics, supplemental oxygen, low-dose lisinopril, and low-dose carvedilol. Symptom improvement was observed. A cardiac MRI showed T2 intramyocardial intensity consistent with edema and early gadolinium enhancement (see Fig. 3) consistent with the Lake Louise Criteria for myocarditis. With additional oral high-dose steroid treatment, her LVEF improved to $50 \%$. She was discharged on prednisone, furosemide, carvedilol, and lisinopril. A few days later she was found hypotensive with systolic blood pressures (SBP) ranging from 60-80 mm Hg and in cardiogenic shock. Hypotension was refractory to IV fluids and dopamine drip. Telemetry showed occasional ventricular bigeminy and trigeminy but no evolving AV block. Serial troponins remained in the $0.1-0.2 \mathrm{ng} / \mathrm{mL}$ range. A repeat echocardiogram at this time showed an EF 60-65\%. Due to the possibility that myocarditis might have been contributing to hypotension and development of autonomic dysfunction as a result of a neurologic irAE, a course of steroids was repeated with methylprednisolone IV $1 \mathrm{~g}$ daily for three days. Additionally, midodrine was started.

Despite medical management, she remained persistently hypotensive. BNP was 1050 $\mathrm{pg} / \mathrm{mL}$ which suggested acute decompensated heart failure. Given her refractory course, two doses of rabbit ATG were given over two days. After the second dose of ATG, her systolic blood pressure improved to greater than $100 \mathrm{~mm}$ of $\mathrm{Hg}$ and cardiogenic shock resolved. Unfortunately, prior to administering the third dose of ATG, the patient was found to have a hemorrhagic stroke on imaging and the family requested comfort care measures.

On autopsy, gross and microscopic findings revealed squamous cell carcinoma diffusely spread to multiple organs, including bilateral lungs, hilum, liver, spleen, heart, kidneys, stomach, small and large intestine, adrenal glands, lymph nodes, mesentery, soft tissue and vertebral bone. Specifically, the intraparenchymal hemorrhage had numerous adjacent vascular tumor thrombi. On gross examination of the heart, multiple white tumor metastatic nodules were noted in the right atrium, septum, right and left ventricle, raising the possibility of an ontarget cardiotoxicity of ICIs directed at the tumor nodules (Fig. 4).

\section{Case 5}

A 67-year-old man with a prior history of coronary artery disease with coronary artery bypass surgery, peripheral arterial disease with stenting in both legs, hypertension, and diabetes mellitus type 2 was diagnosed with stage IIIB metastatic melanoma of the right ear lobule for which he underwent wide local excision. On routine surveillance with positron emission tomography, a metabolically active right upper lobe lung lesion was noted, and the patient underwent right upper lobe wedge resection with negative margins. Further, the patient began treatment with nivolumab $240 \mathrm{mg}$ IV and no complications were noted after completion of three cycles. Prior to receiving the fourth cycle, he presented with a one day history of left-sided chest pain and palpitations. On initial presentation, his labs were notable for troponin-I of $0.31 \mathrm{ng} / \mathrm{mL}$. ECG showed normal sinus rhythm with new lateral ST segment depressions. His chest pain subsequently resolved with nitroglycerin and he was discharged home. He returned the next day for a coronary angiogram which showed patent grafts with no coronary stenoses elsewhere. Given the elevated troponin and a negative coronary angiogram, he 


\section{Case Reports in Oncology}

Case Rep Oncol 2019;12:260-276

DOI: $10.1159 / 000498985$

(C) 2019 The Author(s). Published by S. Karger AG, Basel www.karger.com/cro

Agrawal et al.: Case Series of Cardiac irAEs

was admitted for possible myocarditis. His troponins peaked at $1.55 \mathrm{ng} / \mathrm{mL}$, while creatinine kinase-MB and myoglobin were normal. He then developed new-onset atrial fibrillation/atypical flutter with a rapid ventricular response. An echocardiogram demonstrated mild bi-ventricular dilatation with reduced right ventricular systolic function, bi-atrial dilatation, and an estimated LVEF of $55 \%$.

IV methylprednisolone $1 \mathrm{~g}$ daily for three days was started. Cardiac MRI confirmed the suspicion of myocarditis, with an elevated regional T2 ratio and early gadolinium enhancement ratio suggestive of myocardial edema. Also, there was significant abnormal late gadolinium enhancement involving both basal and mid septal (anterior and inferior septum) and inferolateral segments of the myocardium. The same areas were noted to have abnormal contractility on cine imaging. After clinical improvement on prednisone $80 \mathrm{mg}$ twice daily for 5 days then tapering, he was discharged from the hospital.

On follow-up visit, the patient returned to the hospital twice for recurrent chest pain. Troponin-I peaked at $1.73 \mathrm{ng} / \mathrm{mL}$ although he was free of chest pain throughout. An echocardiogram showed normal left ventricular systolic function and an estimated LVEF of 55-60\%. Repeat cardiac MRI and cine imaging showed global hypokinesis with no abnormal myocardial T2 signal, suggesting a lack of myocardial edema. Chronic sub-endocardial scarring was present. MRI showed that the LVEF had declined from 55 to 31\%. Given recurrent myocarditis, infliximab infusions were started. After the second infusion of infliximab, his troponin levels returned to baseline $(<0.1 \mathrm{ng} / \mathrm{mL})$ and clinical symptoms improved significantly. He ultimately required DC cardioversion for his new onset atrial fibrillation with restoration of normal sinus rhythm.

On a follow-up visit four months after the initial symptom onset, the patient denied having any episodes of chest pain or dyspnea. Unfortunately, he developed optic neuritis, likely an irAE, and was undergoing treatment with long-term oral corticosteroids.

\section{Discussion}

Immune-related adverse events (irAEs) are typically low grade and generally improve with symptomatic management. Grade 3 or higher adverse events have been observed in about $6-21 \%$ of patients receiving ICI monotherapy and around $30 \%$ of patients receiving Ipilimumab-nivolumab combination therapy, and they require more intensive management [37]. Cardiac irAEs are less frequently seen as compared to irAEs in other organ systems, and they can be difficult to diagnose and treat [5]. Preclinical studies have demonstrated that PD1 and PDL1 are expressed in human cardiomyocytes after injury [38]. PD-1 and CTLA-4 deficient mice have been shown to develop dilated cardiomyopathy and myocarditis [39-43]. These animal studies have provided a basic insight into the pathophysiology of ICI-mediated cardio-toxicity [39-43].

A review of the literature found 40 previous case reports describing the occurrence of cardiac irAEs with the use of ICIs (Table 1, Table 2, Table 3). Despite rapid assessment and initiation of immunosuppression, mortality attributed to cardiac irAEs was still high at $23 \%$ ( 9 of 40 cases).

Autoimmune myocarditis was the most common cardiotoxicity observed with the use of ICIs in our review of the literature (29 out of 40 cases, $72 \%$ ). Myocarditis was detected either 


\section{Case Reports in Oncology}

Case Rep Oncol 2019;12:260-276

DOI: $10.1159 / 000498985$

(c) 2019 The Author(s). Published by S. Karger AG, Basel www.karger.com/cro

Agrawal et al.: Case Series of Cardiac irAEs

alone or in the setting of irAEs involving other organ systems, especially musculoskeletal (myositis). All the reviewed cases that developed grade 4 or 5 myocarditis did so after the initial few cycles of ICIs. An eight-center institutional registry found that the prevalence of myocarditis was around $1.14 \%$ among all patients undergoing ICI therapy, with a median time to onset of 34 days after initiation of ICI therapy [36]. Most of these patients had no prior history of cardiac disease and had normal baseline LVEFs and ECGs [36]. Additionally, combination ICI therapy was found to be the main risk factor for the development of ICI-mediated myocarditis [36]. Similarly, in another case series obtained from VigiBase (WHO database) analyzing 101 cases of severe myocarditis following therapy with ICIs, the median time to onset of myocarditis was 30 days after the first dose of ICI, and myocarditis-related fatality was higher in patients who received treatment with a combination of anti-CTLA-4 plus anti-PD-1 or anti-PDL1 compared to monotherapy with either anti-PD-1 or PD-L1 (67 vs. $36 \% ; p=0.008$ ) [44]. Immune-mediated myocarditis has a highly variable clinical presentation ranging from subclinical disease with asymptomatic troponin elevation to recurrent chest pain, cardiogenic shock, conduction abnormalities leading to malignant arrhythmias and sudden death $[7,10$, 12]. In Cases 1 and 2, the patients developed progressive conduction delays and ultimately required transvenous pacing. Case 3 presented with primarily flu-like symptoms and case 4 had the abrupt onset of shortness of breath. Case 5 presented with atypical chest pain with elevated troponin levels concerning for an acute coronary syndrome. These disparate presentations highlight the need for a high degree of clinical vigilance for the diagnosis of myocarditis in patients with ICI use.

The diagnosis of myocarditis can be very challenging and requires a very high index of clinical suspicion. All our cases with prior ICI use had an elevated troponin and abnormal ECG at the time of clinical presentation. Mahmood et al. noted that nearly all cases of myocarditis had a troponin elevation (94\%) and an abnormal ECG (89\%) at the time of presentation [36]. Previously, conduction abnormalities have been widely reported in the setting of immunemediated myocarditis, although they lack sensitivity and specificity for the diagnosis of myocarditis [12]. Cardiac MRI can be a useful diagnostic tool in the early course of the disease, as it can show signs of myocardial inflammation [45]. Endomyocardial biopsy is currently considered to be the gold-standard method for diagnosis of ICI-associated myocarditis. However, pathological false negative cases may be observed, as myocarditis may occur as a patchy distribution of lymphocytic infiltrates adjacent to regions of myocardial necrosis. Given the median time to symptom onset is approximately a month after initiation of ICI therapy, checking the troponin level and ECG at baseline and serially during treatment has been proposed. However, its cost effectiveness remains to be proven. In a prospective evaluation, serial monitoring of troponin levels in a cohort of 59 NSCLC patients treated with nivolumab was done and it was noted that among 362 available blood samples, elevated troponin levels were found in 13 determinations belonging to 6 patients [46]. In only one case was this attributed to a subclinical myocarditis in a patient without a pre-existing cardiac history and in good clinical condition despite sustained elevated troponin levels.

Corticosteroids constitute the first line of therapy for the management of most ICI-related toxicities [47, 48]. High-dose corticosteroids, $1-2 \mathrm{mg} / \mathrm{kg}$ of methylprednisolone followed by an oral steroid taper have been used in the majority of reported cases of immune-mediated myocarditis (Table 1, Table 2, Table 3). A higher initial dose of steroids, methylprednisolone $1,000 \mathrm{mg}$, was associated with a lower rate of Major adverse cardiovascular events (MACE) 


\section{Case Reports in Oncology}

Case Rep Oncol 2019;12:260-276

DOI: $10.1159 / 000498985$

(c)

(C) 2019 The Author(s). Published by S. Karger AG, Base www.karger.com/cro

Agrawal et al.: Case Series of Cardiac irAEs

according to a recent study by Mahmood et al. [36]. However, multiple reports have suggested that corticosteroids alone might not be sufficient to resolve the immune-mediated side effects, and many patients develop malignant arrhythmias and worsening heart failure symptoms while on steroid therapy $[10,12]$. Furthermore, cardiac symptoms should be managed according to the published guidelines from the American College of Cardiology and American Heart Association in collaboration with a cardiologist. Infliximab, a chimeric IgG1 monoclonal antibody that blocks tumor necrosis factor-alpha, a pro-inflammatory cytokine, is used in steroidrefractory immune-related colitis secondary to checkpoint inhibitors [49]. In Case 5 of our study, the patient was started on infliximab infusions after recurrent episodes of steroid-refractory myocarditis. After two infusions of infliximab, he showed significant clinical and biochemical improvement with normalization of troponin-I. Several case reports have documented the use of infliximab in the setting of development of severe-steroid refractory myocarditis [10, 12, 22, 25].

Anti-thymocyte globulin is a polyclonal antibody pool prepared by immunization of horses with lymphoid cells derived from the thymus or cultured B-cell lines. Its indications primarily pertain to allograft rejection and aplastic anemia [50]. Some authors have published on the direct use of ATG for immune-related adverse events, including cardio-toxicity [22, 36, 51]. Two of our patients received ATG therapy after a deteriorating clinical course while on steroids. Both patients responded well to ATG therapy with resolution of malignant arrhythmias and cardiogenic shock. In one patient after three doses of ATG, the conduction abnormalities had improved from complete heart block to sinus rhythm with second degree heart block and only occasional dropped beats. In the second case, the patient had refractory hypotension in the setting of cardiogenic shock due to fulminant myocarditis. She received a single dose of ATG, which led to significant improvement in her blood pressure with resolution of cardiogenic shock. As suggested by Tay et al., it is hypothesized that ATG results in the rapid reduction of T-cell hyper-activation and decreased lymphocytic infiltration, thus leading to improvement in myocardial conduction [22].

Although uncommon, potentially fatal cardiovascular adverse events can occur as a side effect of ICI. This case series highlights the importance of high clinical suspicion, early diagnosis of myocarditis and prompt initiation of infliximab and ATG in the management of toxicities in steroid refractory patients. Also, even in asymptomatic patients with prior ICI use, an abnormal elevation in troponin-I and conduction abnormalities on the ECG warrant an urgent referral to a cardiologist.

\section{Conclusion}

Checkpoint inhibitor use may lead to the development of cardiotoxic adverse events such as myocarditis, conduction abnormalities, cardiomyopathy, pericarditis and acute coronary syndrome. It is essential for clinicians to be aware of these adverse events because of a higher risk for mortality. Assessment of clinical features with a combination of blood chemistry analysis, electrocardiography, cardiac imaging, and endomyocardial biopsy may be useful to facilitate the diagnosis. Aggressive treatment with high dose corticosteroids and immunomodulators such as infliximab, mycophenolate, intravenous immunoglobulin, and antithymocyte globulin, and/or plasmapheresis may lead to functional improvement and increased survival. 
The value of baseline cardiac function assessment and frequent monitoring warrants prospective validation, especially for individuals who may be at high risk of developing clinically significant complications from immune-related cardiotoxicity, such as in patients with pre-existing cardiac disease or autoimmune disease.

\section{Statement of Ethics}

All the procedures followed were in accordance with the ethical standards of the responsible committee on human experimentation (institution and national) and with the Helsinki Declaration of 1964. Informed consent was obtained from the patients.

\section{Disclosure Statement}

The authors have no relevant conflicts of interest to report.

\section{Funding Sources}

No financial support was utilized in the preparation of this manuscript.

\section{Author Contributions}

PV designed the study, collected data, analyzed data, and wrote the manuscript.

NA, AK, TC collected the data, analyzed data, and edited the manuscript.

$\mathrm{AH}, \mathrm{ES}, \mathrm{AC}, \mathrm{GD}, \mathrm{ME}$, IP were involved in critical revision of the manuscript for important intellectual content.

\section{References}

1 Pardoll DM. The blockade of immune checkpoints in cancer immunotherapy. Nat Rev Cancer. 2012 Mar;12(4):252-64.

2 Allison JP. Immune Checkpoint Blockade in Cancer Therapy: The 2015 Lasker-DeBakey Clinical Medical Research Award. JAMA. 2015 Sep;314(11):1113-4.

3 Park YJ, Kuen DS, Chung Y. Future prospects of immune checkpoint blockade in cancer: from response prediction to overcoming resistance. Exp Mol Med. 2018 Aug;50(8):109.

4 Komaki Y, Komaki F, Yamada A, Micic D, Ido A, Sakuraba A. Meta-Analysis of the Risk of Immune-Related Adverse Events With Anticytotoxic T-Lymphocyte-Associated Antigen 4 and Antiprogrammed Death 1 Therapies. Clin Pharmacol Ther. 2018 Feb;103(2):318-31.

5 Puzanov I, Diab A, Abdallah K, Bingham CO 3rd, Brogdon C, Dadu R, et al.; Society for Immunotherapy of Cancer Toxicity Management Working Group. Managing toxicities associated with immune checkpoint inhibitors: consensus recommendations from the Society for Immunotherapy of Cancer (SITC) Toxicity Management Working Group. J Immunother Cancer. 2017 Nov;5(1):95.

6 Michot JM, Bigenwald C, Champiat S, Collins M, Carbonnel F, Postel-Vinay S, et al. Immune-related adverse events with immune checkpoint blockade: a comprehensive review. Eur J Cancer. 2016 Feb;54:139-48. 
7 Läubli H, Balmelli C, Bossard M, Pfister O, Glatz K, Zippelius A. Acute heart failure due to autoimmune myocarditis under pembrolizumab treatment for metastatic melanoma. J Immunother Cancer. 2015 Apr;3(1):11.

8 Geisler BP, Raad RA, Esaian D, Sharon E, Schwartz DR. Apical ballooning and cardiomyopathy in a melanoma patient treated with ipilimumab: a case of takotsubo-like syndrome. J Immunother Cancer. 2015 Feb;3(1):4.

9 Yun S, Vincelette NC, Mansour I, Hariri D, Motamed S. Late onset ipilimumab-induced pericarditis and pericardial effusion: a rare but life threatening complication. Case Rep Oncol Med. 2015;794842.

10 Heinzerling L, Ott PA, Hodi FS, Husain AN, Tajmir-Riahi A, Tawbi H, et al. Cardiotoxicity associated with CTLA4 and PD1 blocking immunotherapy. J Immunother Cancer. 2016 Aug;4(1):50.

11 Tadokoro T, Keshino E, Makiyama A, Sasaguri T, Ohshima K, Katano H, et al. Acute lymphocytic myocarditis with anti-PD-1 antibody nivolumab. Circ Heart Fail. 2016 Oct;9(10):e003514.

12 Johnson DB, Balko JM, Compton ML, Chalkias S, Gorham J, Xu Y, et al. Fulminant myocarditis with combination immune checkpoint blockade. N Engl J Med. 2016 Nov;375(18):1749-55.

13 Semper H, Muehlberg F, Schulz-Menger J, Allewelt M, Grohé C. Drug-induced myocarditis after nivolumab treatment in a patient with PDL1- negative squamous cell carcinoma of the lung. Lung Cancer. 2016 Sep;99:117-9.

14 Gibson R, Delaune J, Szady A, Markham M. Suspected autoimmune myocarditis and cardiac conduction abnormalities with nivolumab therapy for non-small cell lung cancer. BMJ Case Rep. 2016 Jul;2016:bcr2016216228.

15 Mehta A, Gupta A, Hannallah F, Koshy T, Reimold S. Myocarditis as an immune-related adverse event with ipilimumab/nivolumab combination therapy for metastatic melanoma. Melanoma Res. 2016 Jun;26(3):31920.

16 Zimmer L, Goldinger SM, Hofmann L, Loquai C, Ugurel S, Thomas I, et al. Neurological, respiratory, musculoskeletal, cardiac and ocular side-effects of anti-PD-1 therapy. Eur J Cancer. 2016 Jun;60:210-25.

17 Berg DD, Vaduganathan M, Nohria A, Davids MS, Alyea EP, Torre M, et al. Immune-related fulminant myocarditis in a patient receiving ipilimumab therapy for relapsed chronic myelomonocytic leukaemia. Eur ] Heart Fail. 2017 May;19(5):682-5.

18 Behling J, Kaes J, Münzel T, Grabbe S, Loquai C. New-onset third-degree atrioventricular block because of autoimmune-induced myositis under treatment with anti-programmed cell death-1 (nivolumab) for metastatic melanoma. Melanoma Res. 2017 Apr;27(2):155-8.

19 Arangalage D, Delyon J, Lermuzeaux M, Ekpe K, Ederhy S, Pages C, et al. Survival after fulminant myocarditis induced by immune-checkpoint inhibitors. Ann Intern Med. 2017 Nov;167(9):683-4.

20 Chauhan A, Burkeen G, Houranieh J, Arnold S, Anthony L. Immune checkpoint-associated cardiotoxicity: case report with systematic review of literature. Ann Oncol. 2017 Aug;28(8):2034-8.

21 Tomita Y, Sueta D, Kakiuchi Y, Saeki S, Saruwatari K, Sakata S, et al. Acute coronary syndrome as a possible immune-related adverse event in a lung cancer patient achieving a complete response to anti-PD-1 immune checkpoint antibody. Ann Oncol. 2017 Nov;28(11):2893-5.

22 Tay RY, Blackley E, McLean C, Moore M, Bergin P, Gill S, et al. Successful use of equine anti-thymocyte globulin (ATGAM) for fulminant myocarditis secondary to nivolumab therapy. Br J Cancer. 2017 Sep;117(7):921-4.

23 Fukasawa Y, Sasaki K, Natsume M, Nakashima M, Ota S, Watanabe K, et al. Nivolumab-induced myocarditis concomitant with myasthenia gravis. Case Rep Oncol. 2017 Sep;10(3):809-12.

24 Norwood TG, Westbrook BC, Johnson DB, Litovsky SH, Terry NL, McKee SB, et al. Smoldering myocarditis following immune checkpoint blockade. J Immunother Cancer. 2017 Nov;5(1):91.

25 Frigeri M, Meyer P, Banfi C, Giraud R, Hachulla AL, Spoerl D, et al. Immune checkpoint inhibitor-associated myocarditis: a new challenge for cardiologists. Can J Cardiol. 2018 Jan;34(1):92.e1-92.e3.

26 Nasr F, El Rassy E, Maalouf G, Azar C, Haddad F, Helou J, et al. Severe ophthalmoplegia and myocarditis following the administration of pembrolizumab. Eur J Cancer. 2018 Mar;91:171-3.

27 Matson DR, Accola MA, Rehrauer WM, Corliss RF. Fatal Myocarditis Following Treatment with the PD-1 Inhibitor Nivolumab. J Forensic Sci. 2018 May;63(3):954-7.

28 Mahmood SS, Chen CL, Shapnik N, Krishnan U, Singh HS, Makker V. Myocarditis with tremelimumab plus durvalumab combination therapy for endometrial cancer: A case report. Gynecol Oncol Rep. 2018 Jun;25:74-7.

29 Yamaguchi S, Morimoto R, Okumura T, Yamashita Y, Haga T, Kuwayama T, et al. Late-Onset Fulminant Myocarditis With Immune Checkpoint Inhibitor Nivolumab. Can J Cardiol. 2018 Jun;34(6):812.e1-812.e3.

30 Trachtenberg B, Hussain F, Mukherjee A, Araujo-Gutierrez R, Pingali SR. Immune Checkpoint InhibitorRelated Cardiotoxicity. Methodist Debakey Cardiovasc J. 2018 Jul-Sep;14(3):e1-4. 
31 Ferreira M, Pichon E, Carmier D, Bouquet E, Pageot C, Bejan-Angoulvant T, et al. Coronary Toxicities of AntiPD-1 and Anti-PD-L1 Immunotherapies: a Case Report and Review of the Literature and International Registries. Target Oncol. 2018 Aug;13(4):509-15.

32 Jain V, Mohebtash M, Rodrigo ME, Ruiz G, Atkins MB, Barac A. Autoimmune Myocarditis Caused by Immune Checkpoint Inhibitors Treated With Antithymocyte Globulin. J Immunother. 2018 Sep;41(7):332-5.

33 Imai R, Ono M, Nishimura N, Suzuki K, Komiyama N, Tamura T. Fulminant myocarditis caused by an immune checkpoint inhibitor: A case report with pathologic findings. J Thorac Oncol. 2018.

34 Rota E, Varese P, Agosti S, Celli L, Ghiglione E, Pappalardo I, et al. Concomitant myasthenia gravis, myositis, myocarditis and polyneuropathy, induced by immune-checkpoint inhibitors: A life-threatening continuum of neuromuscular and cardiac toxicity. eNeurologicalSci. 2018 Nov 22;14:4-5.

35 Katsume Y, Isawa T, Toi Y, Fukuda R, Kondo Y, Sugawara S, et al. Complete Atrioventricular Block Associated with Pembrolizumab-induced Acute Myocarditis: The Need for Close Cardiac Monitoring. Intern Med. 2018 Nov;57(21):3157-62.

36 Mahmood SS, Fradley MG, Cohen JV, Nohria A, Reynolds KL, Heinzerling LM, et al. Myocarditis in patients treated with immune checkpoint inhibitors. J Am Coll Cardiol. 2018 Apr;71(16):1755-64.

37 El Osta B, Hu F, Sadek R, Chintalapally R, Tang SC. Not all immune-checkpoint inhibitors are created equal: meta-analysis and systematic review of immune-related adverse events in cancer trials. Crit Rev Oncol Hematol. 2017 Nov;119:1-12.

38 Varricchi G, Galdiero MR, Tocchetti CG. Cardiac Toxi city of Immune Checkpoint Inhibitors: Cardio-Oncology Meets Immunology. Circulation. 2017 Nov;136(21):1989-92.

39 Nishimura H, Okazaki T, Tanaka Y, Nakatani K, Hara M, Matsumori A, et al. Autoimmune dilated cardiomyopathy in PD-1 receptor-deficient mice. Science. 2001 Jan;291(5502):319-22.

40 Okazaki T, Tanaka Y, Nishio R, Mitsuiye T, Mizoguchi A, Wang J, et al. Autoantibodies against cardiac troponin I are responsible for dilated cardiomyopathy in PD-1-deficient mice. Nat Med. 2003 Dec;9(12):1477-83.

41 Wang J, Okazaki IM, Yoshida T, Chikuma S, Kato Y, Nakaki F, et al. PD-1 deficiency results in the development of fatal myocarditis in MRL mice. Int Immunol. 2010 Jun;22(6):443-52.

42 Boutros C, Tarhini A, Routier E, Lambotte O, Ladurie FL, Carbonnel F, et al. Safety profiles of anti-CTLA-4 and anti-PD-1 antibodies alone and in combination. Nat Rev Clin Oncol. 2016 Aug;13(8):473-86.

43 Waterhouse P, Penninger JM, Timms E, Wakeham A, Shahinian A, Lee KP, et al. Lymphoproliferative disorders with early lethality in mice deficient in Ctla-4. Science. 1995 Nov;270(5238):985-8.

44 Salem JE, Manouchehri A, Moey M, Lebrun-Vignes B, Bastarache L, Pariente A, et al. Cardiovascular toxicities associated with immune checkpoint inhibitors: an observational, retrospective, pharmacovigilance study. Lancet Oncol. 2018 Dec;19(12):1579-89.

45 Aquaro GD, Perfetti M, Camastra G, Monti L, Dellegrottaglie S, Moro C, et al.; Cardiac Magnetic Resonance Working Group of the Italian Society of Cardiology. Cardiac MR with late gadolinium enhancement in acute myocarditis with preserved systolic function: ITAMY study. J Am Coll Cardiol. 2017 Oct;70(16):1977-87.

46 Sarocchi M, Grossi F, Arboscello E, Bellodi A, Genova C, Dal Bello MG, et al. Serial Troponin for Early Detection of Nivolumab Cardiotoxicity in Advanced Non-Small Cell Lung Cancer Patients. Oncologist. 2018 Aug;23(8):936-942.

47 Haanen JBAG, Carbonnel F, Robert C, Kerr KM, Peters S, Larkin J, et al. Management of toxicities from immunotherapy: ESMO Clinical Practice Guidelines for diagnosis, treatment and follow-up. Ann Oncol. 2017 Jul 1;28(suppl_4):iv119-42.

48 Brahmer JR, Lacchetti C, Schneider BJ, Atkins MB, Brassil KJ, Caterino JM, et al.; National Comprehensive Cancer Network. Management of immune-related adverse events in patients treated with immune checkpoint inhibitor therapy: American Society of Clinical Oncology Clinical Practice Guideline. J Clin Oncol. 2018 Jun;36(17):1714-68.

49 Pagès $C$, Gornet JM, Monsel G, Allez M, Bertheau P, Bagot M, et al. Ipilimumab-induced acute severe colitis treated by infliximab. Melanoma Res. 2013 Jun;23(3):227-30.

50 Rosenfeld SJ, Kimball J, Vining D, Young NS. Intensive immunosuppression with antithymocyte globulin and cyclosporine as treatment for severe acquired aplastic anemia. Blood. 1995 Jun;85(11):3058-65.

51 Jain V, Bahia J, Mohebtash M, Barac A. Cardiovascular Complications Associated With Novel Cancer Immunotherapies. Curr Treat Options Cardiovasc Med. 2017 May;19(5):36. 


\section{Case Reports in Oncology}

Case Rep Oncol 2019;12:260-276
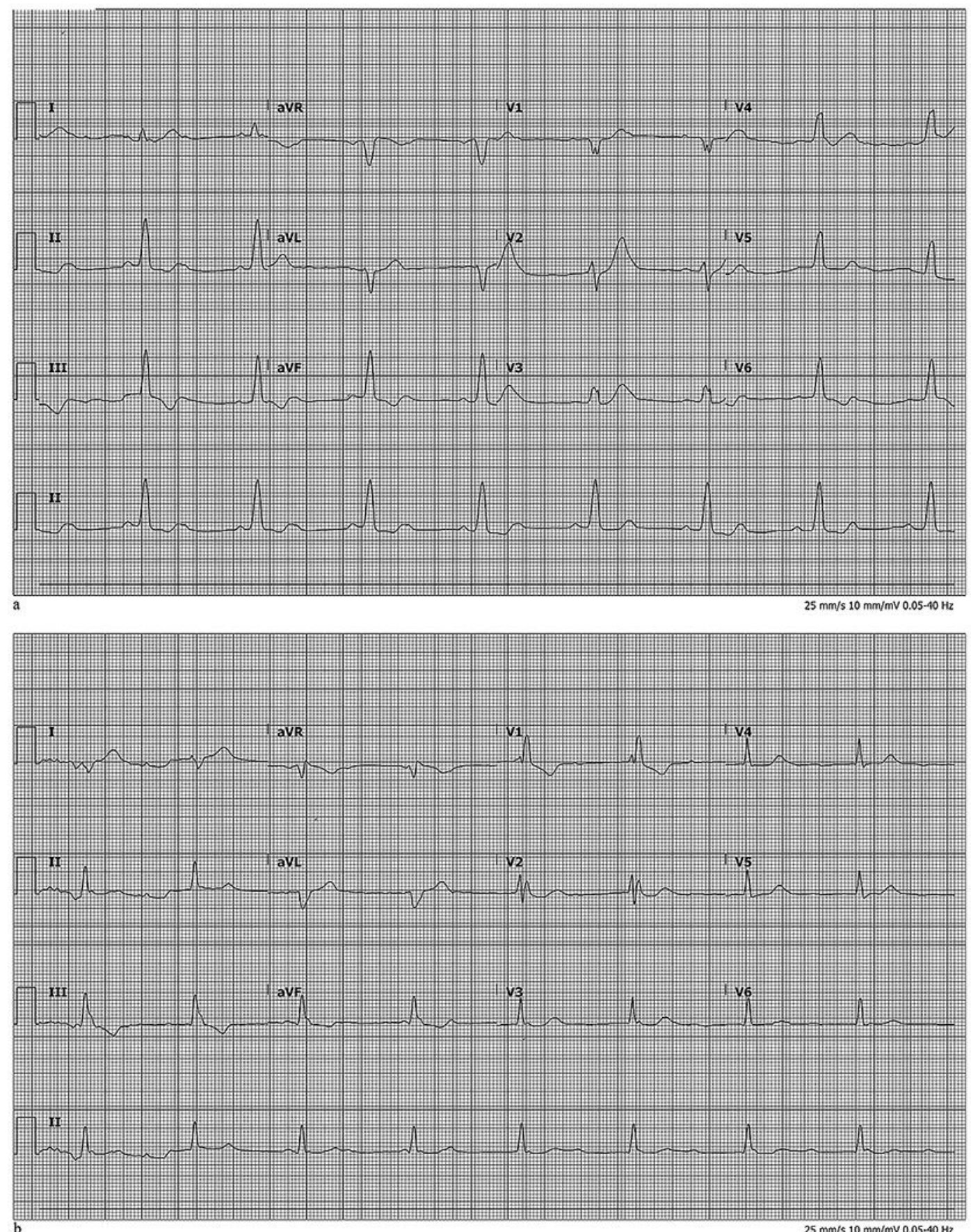

Fig. 1. Case 1: EKG changes observed on day 32 after 1 dose of pembrolizumab $200 \mathrm{mg}$ infusion showing left bundle branch block (a) and right bundle branch block (b). 


\section{Case Reports in Oncology}

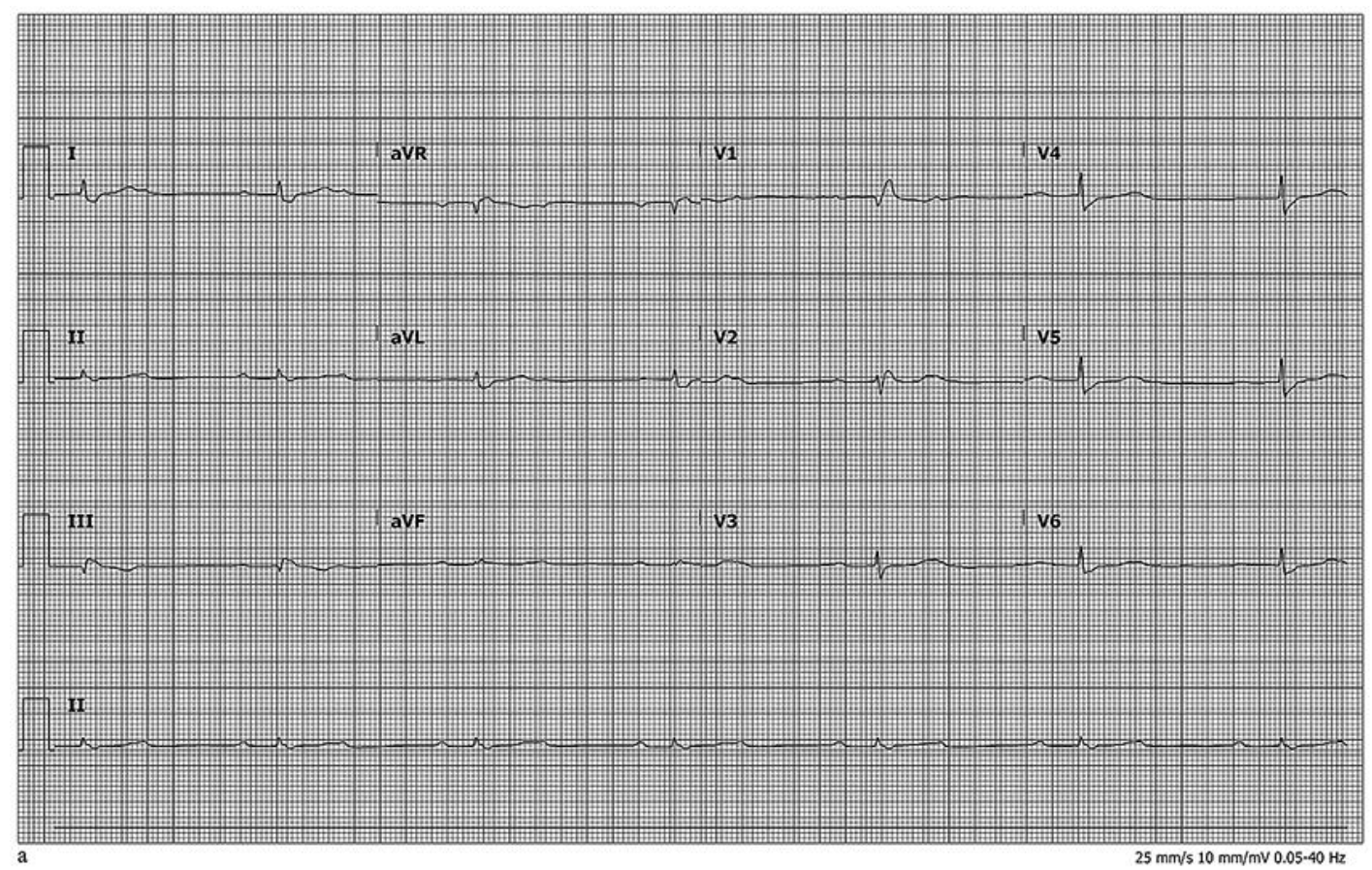

Fig. 2. Case 3: EKG changes observed on day 12 after 1 dose of pembrolizumab $2 \mathrm{mg} / \mathrm{kg}$ infusion showing right bundle branch block. 


\section{Case Reports in Oncology}

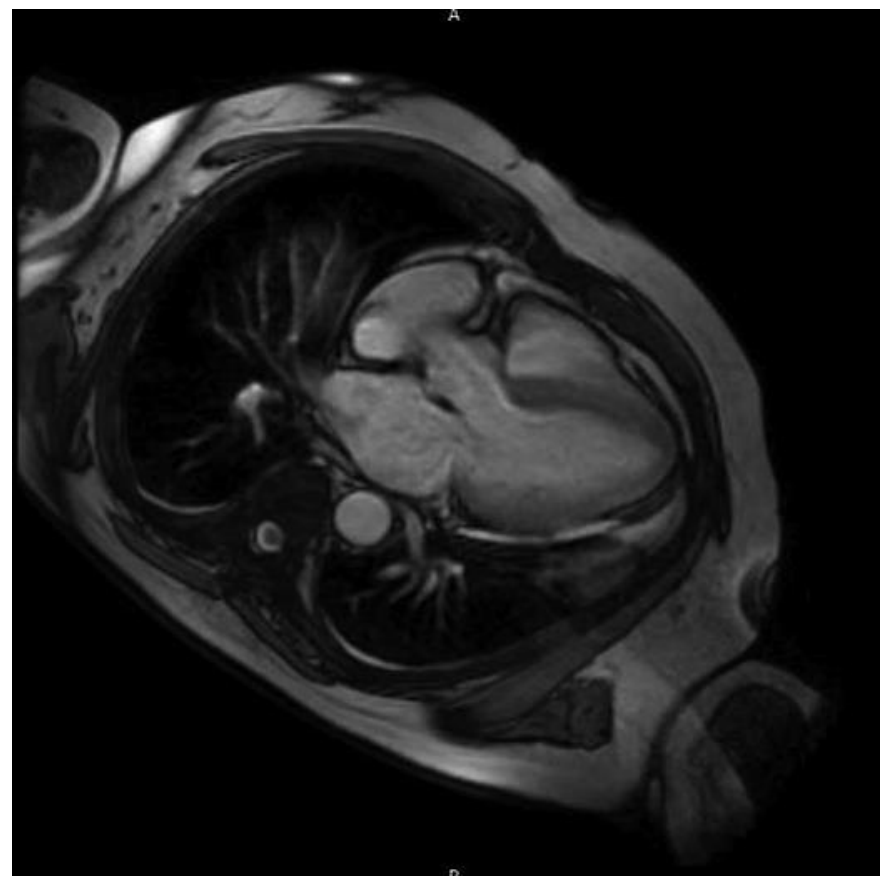

(C) 2019 The Author(s). Published by S. Karger AG, Basel www.karger.com/cro

Agrawal et al.: Case Series of Cardiac irAEs

Fig. 3. Case 4: Cardiac MRI showed T2 intramyocardial intensity consistent with edema and early gadolinium enhancement, consistent with the Lake Louise Criteria for myocarditis.

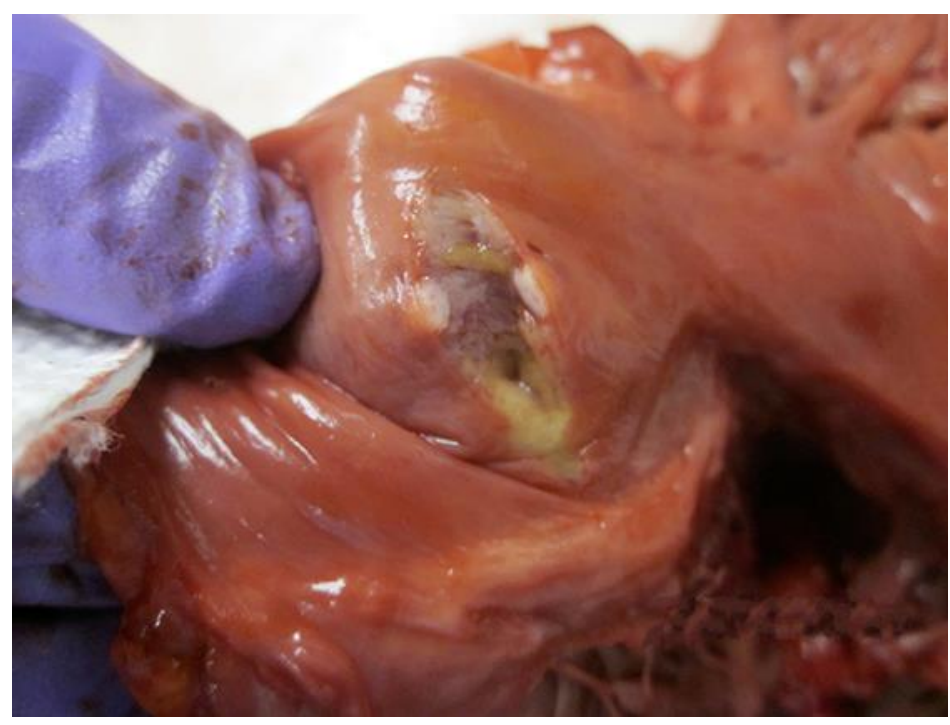

Fig. 4. Case 4: Autopsy specimen of the heart demonstrating multiple white tumor metastatic nodules in the right atrium. 
Table 1. Summary of all notable cases of cardiac toxicities from immune checkpoint inhibitors

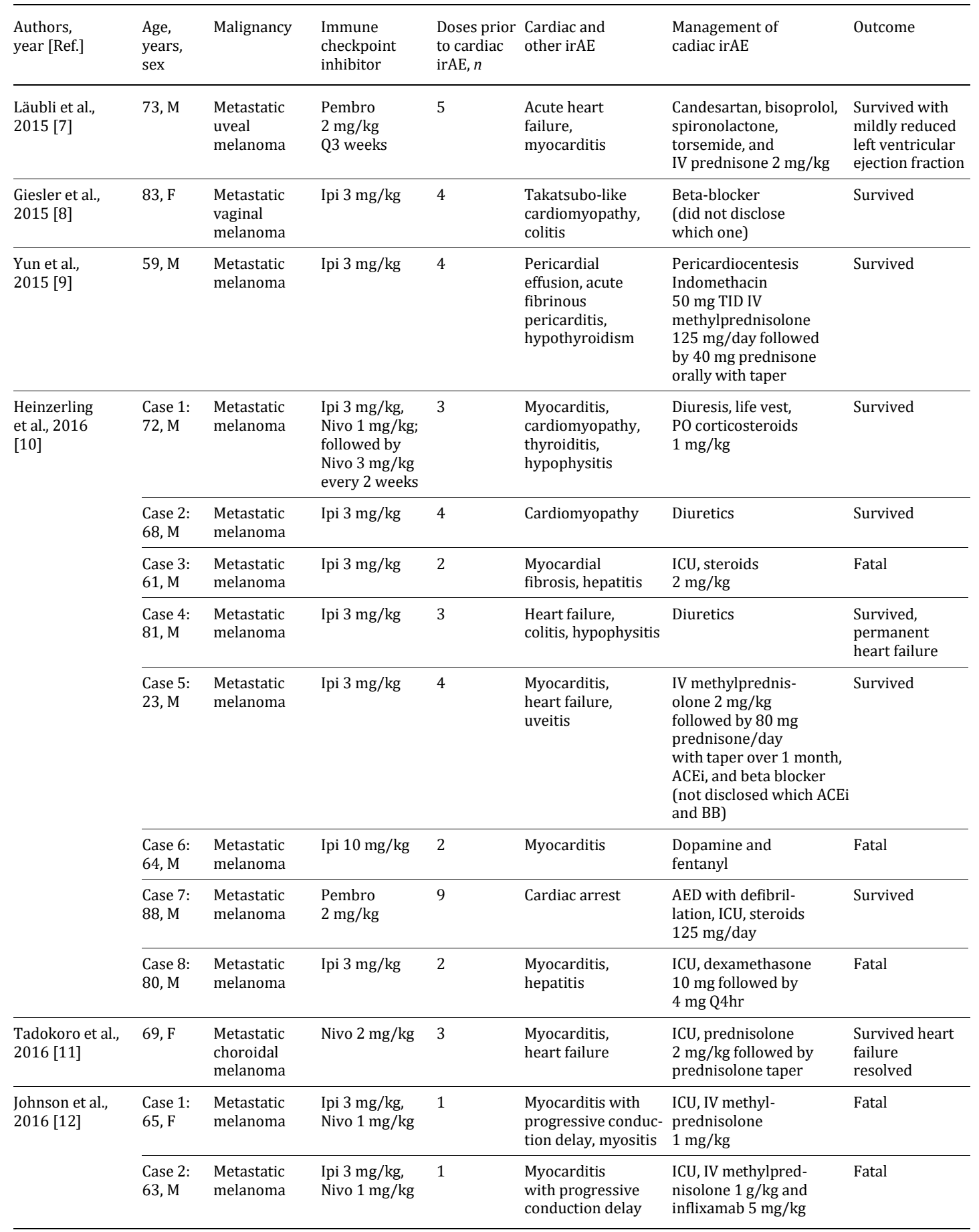

AED, automated external defibrillator; ATGAM, anti-thymocyte globulin; ECMO, extracorporeal membrane oxygenation; ICU, intensive care unit; irAE, immune-related adverse event; IV, intravenous; IVIG, intravenous immunoglobulin; ipi, ipilimumab; mg/kg, milligram $/ \mathrm{kilogram}$ body weight; NA, not available; nivo, nivolumab; pembro, pembrolizumab. 
Table 2. Summary of all notable cases of cardiac toxicities from immune checkpoint inhibitors (continued)

\begin{tabular}{|c|c|c|c|c|c|c|c|}
\hline $\begin{array}{l}\text { Authors, } \\
\text { year [Ref.] }\end{array}$ & $\begin{array}{l}\text { Age, } \\
\text { years, } \\
\text { sex }\end{array}$ & Malignancy & $\begin{array}{l}\text { Immune } \\
\text { checkpoint } \\
\text { inhibitor }\end{array}$ & $\begin{array}{l}\text { Doses } \\
\text { prior to } \\
\text { cardiac } \\
\text { irAE, } n\end{array}$ & $\begin{array}{l}\text { Cardiac and } \\
\text { other irAE }\end{array}$ & $\begin{array}{l}\text { Management of } \\
\text { cadiac irAE }\end{array}$ & Outcome \\
\hline $\begin{array}{l}\text { Semper } \\
\text { et al., } 2016\end{array}$ & $75, \mathrm{M}$ & $\begin{array}{l}\text { Squamous } \\
\text { cell carcino- } \\
\text { ma of lung }\end{array}$ & Nivo 3 mg/kg & 8 & Myocarditis & $\begin{array}{l}\text { ACE-inhibitors, } \beta \text {-blockers, } \\
\text { diuretics, prednisolone } \\
(1 \mathrm{mg} / \mathrm{kg} / \text { day })\end{array}$ & Survived \\
\hline $\begin{array}{l}\text { Gibson et al., } \\
2016 \text { [14] }\end{array}$ & $68, \mathrm{~F}$ & $\begin{array}{l}\text { Lung adeno- } \\
\text { carcinoma }\end{array}$ & $\begin{array}{l}\text { Nivo } \\
\text { (dose NA) }\end{array}$ & 3 & $\begin{array}{l}\text { Myocarditis, } \\
\text { cardiac conduction } \\
\text { abnormalities }\end{array}$ & $\begin{array}{l}\text { IV methylprednisolone } \\
\text { and amiodarone } \\
\text { infusion }\end{array}$ & Survived \\
\hline $\begin{array}{l}\text { Mehta et al., } \\
2016 \text { [15] }\end{array}$ & $68, \mathrm{~F}$ & $\begin{array}{l}\text { Metastatic } \\
\text { melanoma }\end{array}$ & $\begin{array}{l}\text { Nivo-Ipi } \\
\text { combination } \\
\text { (dose NA) }\end{array}$ & 2 & Myocarditis & $\begin{array}{l}1 \mathrm{mg} / \mathrm{kg} \text { IV methyl- } \\
\text { prednisolone }\end{array}$ & Resolved \\
\hline \multirow[t]{3}{*}{$\begin{array}{l}\text { Zimmer et al., } \\
2016 \text { [16] }\end{array}$} & $\begin{array}{l}\text { Case 1: } \\
73, \mathrm{M}\end{array}$ & Melanoma & Pembro & 1 & $\begin{array}{l}\text { Myocarditis with } \\
\text { cardiomyopathy }\end{array}$ & $\begin{array}{l}\text { Prednisolone } \\
1 \mathrm{mg} / \mathrm{kg} / \text { day oral }\end{array}$ & Survived \\
\hline & $\begin{array}{l}\text { Case 2: } \\
87, \mathrm{M}\end{array}$ & Melanoma & Nivo & $\begin{array}{l}17 \text { weeks } \\
\text { after therapy } \\
\text { initiation }\end{array}$ & Asystole & $\begin{array}{l}\text { Prednisolone } \\
125 \mathrm{mg} / \mathrm{d} \text { i.v. }\end{array}$ & Survived \\
\hline & $\begin{array}{l}\text { Case } 3: \\
77, \mathrm{M}\end{array}$ & Melanoma & Pembro & $\begin{array}{l}10 \text { weeks } \\
\text { after therapy } \\
\text { initiation }\end{array}$ & $\begin{array}{l}\text { Stable angina } \\
\text { pectoris }\end{array}$ & Stopped pembro & Survived \\
\hline $\begin{array}{l}\text { Berg et al., } \\
2017 \text { [17] }\end{array}$ & $66, \mathrm{M}$ & $\begin{array}{l}\text { Chronic } \\
\text { myelo- } \\
\text { monocytic } \\
\text { leukemia }\end{array}$ & $\begin{array}{l}\text { Ipi (dose } \\
\text { NA) }\end{array}$ & 1 & $\begin{array}{l}\text { Acute heart } \\
\text { failure with } \\
\text { progressive } \\
\text { conduction } \\
\text { delay, colitis }\end{array}$ & $\begin{array}{l}\text { 7-day dexamethasone } \\
\text { taper followed by ICU, } \\
\text { diuretic, and IV } \\
\text { methylprednisolone } \\
1,000 \mathrm{mg} / \text { day }\end{array}$ & Fatal \\
\hline $\begin{array}{l}\text { Behling et al., } \\
2017 \text { [18] }\end{array}$ & $63, \mathrm{M}$ & $\begin{array}{l}\text { Metastatic } \\
\text { uveal } \\
\text { melanoma }\end{array}$ & $\begin{array}{l}\text { Nivo } \\
3 \mathrm{mg} / \mathrm{kg}\end{array}$ & 2 & $\begin{array}{l}\text { Myositis with } \\
\text { progressive } \\
\text { conduction delay }\end{array}$ & $\begin{array}{l}\text { ICU, IV prednisone } \\
1.5 \mathrm{mg} / \mathrm{kg}\end{array}$ & Fatal \\
\hline $\begin{array}{l}\text { Arangalage } \\
\text { et al., } 2017 \\
{[19]}\end{array}$ & $35, \mathrm{~F}$ & $\begin{array}{l}\text { Stage IIIc } \\
\text { melanoma }\end{array}$ & $\begin{array}{l}\text { Ipi } 3 \mathrm{mg} / \mathrm{kg} \text {, } \\
\text { Nivo } \\
1 \mathrm{mg} / \mathrm{kg}\end{array}$ & 1 & $\begin{array}{l}\text { Fulminant } \\
\text { myocarditis } \\
\text { hyperthyroid, } \\
\text { myositis }\end{array}$ & $\begin{array}{l}\text { ICU, IV solumedrol } 1 \mathrm{~g} / \mathrm{day} \\
\text { and IVIG followed by ECMO } \\
\text { and plasma exchange } \\
\text { followed by tacrolimus } \\
\text { (target blood level } \\
10-15 \mathrm{ng} / \mathrm{mL} \text { ) }\end{array}$ & $\begin{array}{l}\text { Survived, } \\
\text { heart failure } \\
\text { resolved }\end{array}$ \\
\hline $\begin{array}{l}\text { Chauhan et al., } \\
2017 \text { [20] }\end{array}$ & $64, \mathrm{M}$ & $\begin{array}{l}\text { Metastatic } \\
\text { lung adeno- } \\
\text { carcinoma }\end{array}$ & Nivo & 1 & Myocarditis & $\begin{array}{l}\text { Prednisone, heart } \\
\text { failure medications }\end{array}$ & $\begin{array}{l}\text { Survived, } \\
\text { similar } \\
\text { symptoms } \\
1 \text { week after } \\
\text { rechallenge } \\
\text { with Nivo }\end{array}$ \\
\hline $\begin{array}{l}\text { Tomita et al., } \\
2017 \text { [21] }\end{array}$ & $61, \mathrm{M}$ & $\begin{array}{l}\text { Metastatic } \\
\text { lung adeno- } \\
\text { carcinoma }\end{array}$ & Nivo & 11 & $\begin{array}{l}\text { Acute } \\
\text { coronary } \\
\text { syndrome }\end{array}$ & $\begin{array}{l}\text { Stenting of right } \\
\text { coronary artery }\end{array}$ & Survived \\
\hline $\begin{array}{l}\text { Tay et al., } \\
2017 \text { [22] }\end{array}$ & $64, F$ & Glioblastoma & $\begin{array}{l}\text { Temozolo- } \\
\text { mide+ Nivo } \\
+ \text { radiation } \\
\text { therapy }\end{array}$ & 2 & Myocarditis & $\begin{array}{l}\text { IV methylprednisolone } \\
500 \text { mg daily for } 3 \text { days } \\
\mathrm{f} / \mathrm{b} \text { Single dose of IV } \\
\text { infliximab } 5 \mathrm{mg} / \mathrm{kg} \\
\text { on day } 2 \\
\text { Day 8, equine ATGAM } \\
\text { therapy }\end{array}$ & Survived \\
\hline $\begin{array}{l}\text { Fukasawa } \\
\text { et al., } 2017 \\
{[23]}\end{array}$ & $69, \mathrm{~F}$ & $\begin{array}{l}\text { Metastatic } \\
\text { lung adeno- } \\
\text { carcinoma }\end{array}$ & $\begin{array}{l}\text { Nivo } \\
\text { (dose NA) }\end{array}$ & 3 & Myocarditis & $\begin{array}{l}\text { IV methylprednisolone } \\
1,000 \mathrm{mg} \text { for } 3 \text { days fol- } \\
\text { lowed by } 1 \mathrm{mg} / \mathrm{kg} / \text { day }\end{array}$ & Survived \\
\hline
\end{tabular}

AED, automated external defibrillator; ATGAM, anti-thymocyte globulin; ECMO, extracorporeal membrane oxygenation; ICU, intensive care unit; irAE, immune-related adverse event; IV, intravenous; IVIG, intravenous immunoglobulin; ipi, ipilimumab; mg/kg, milligram/kilogram body weight; NA, not available; nivo, nivolumab; pembro, pembrolizumab. 
Table 3. Summary of all notable cases of cardiac toxicities from immune checkpoint inhibitors (continued)

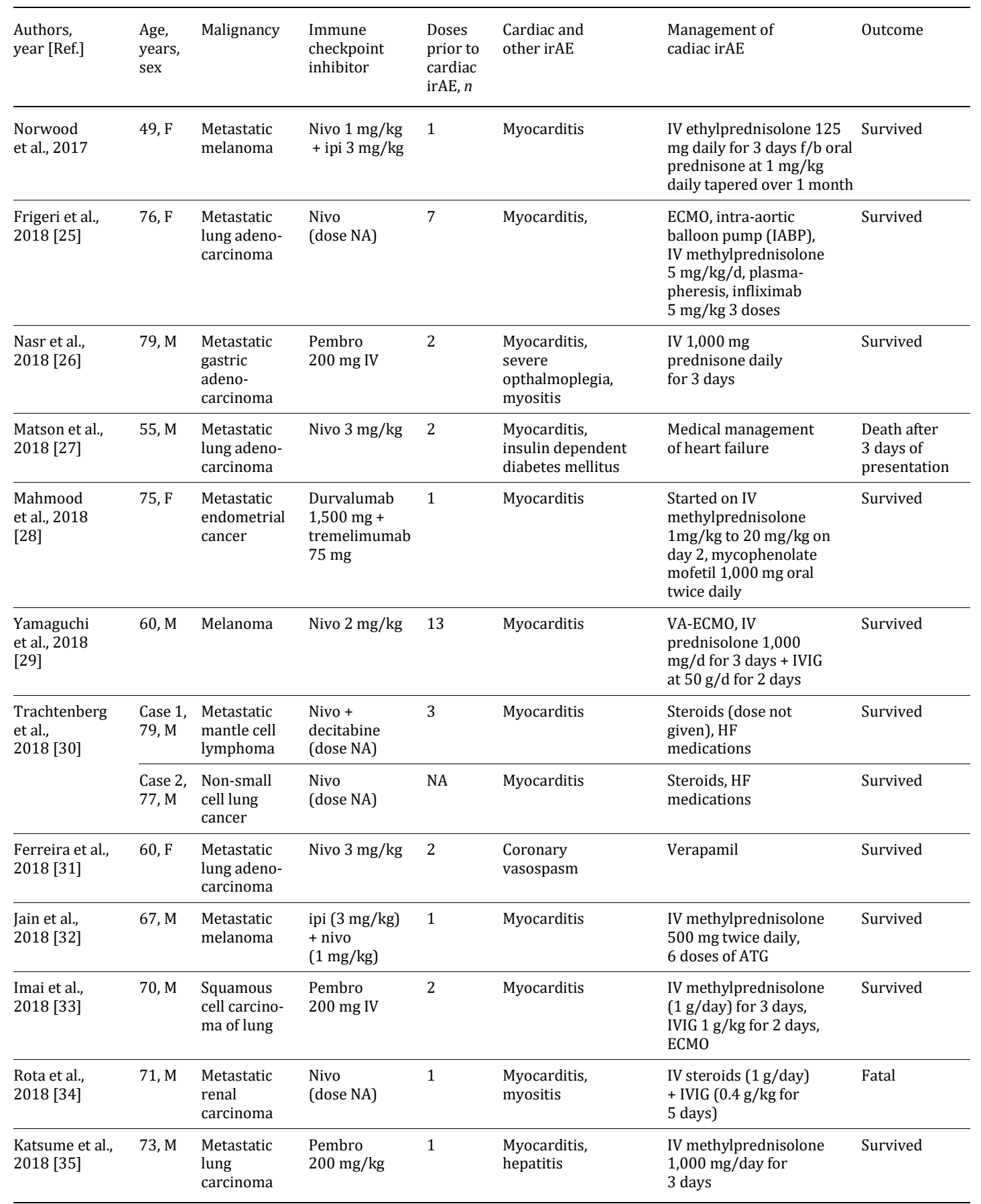

AED, automated external defibrillator; ATGAM, anti-thymocyte globulin; ECMO, extracorporeal membrane oxygenation; ICU, intensive care unit; irAE, immune-related adverse event; IV, intravenous; IVIG, intravenous immunoglobulin; ipi, ipilimumab; mg/kg, milligram/kilogram body weight; NA, not available; nivo, nivolumab; pembro, pembrolizumab. 